
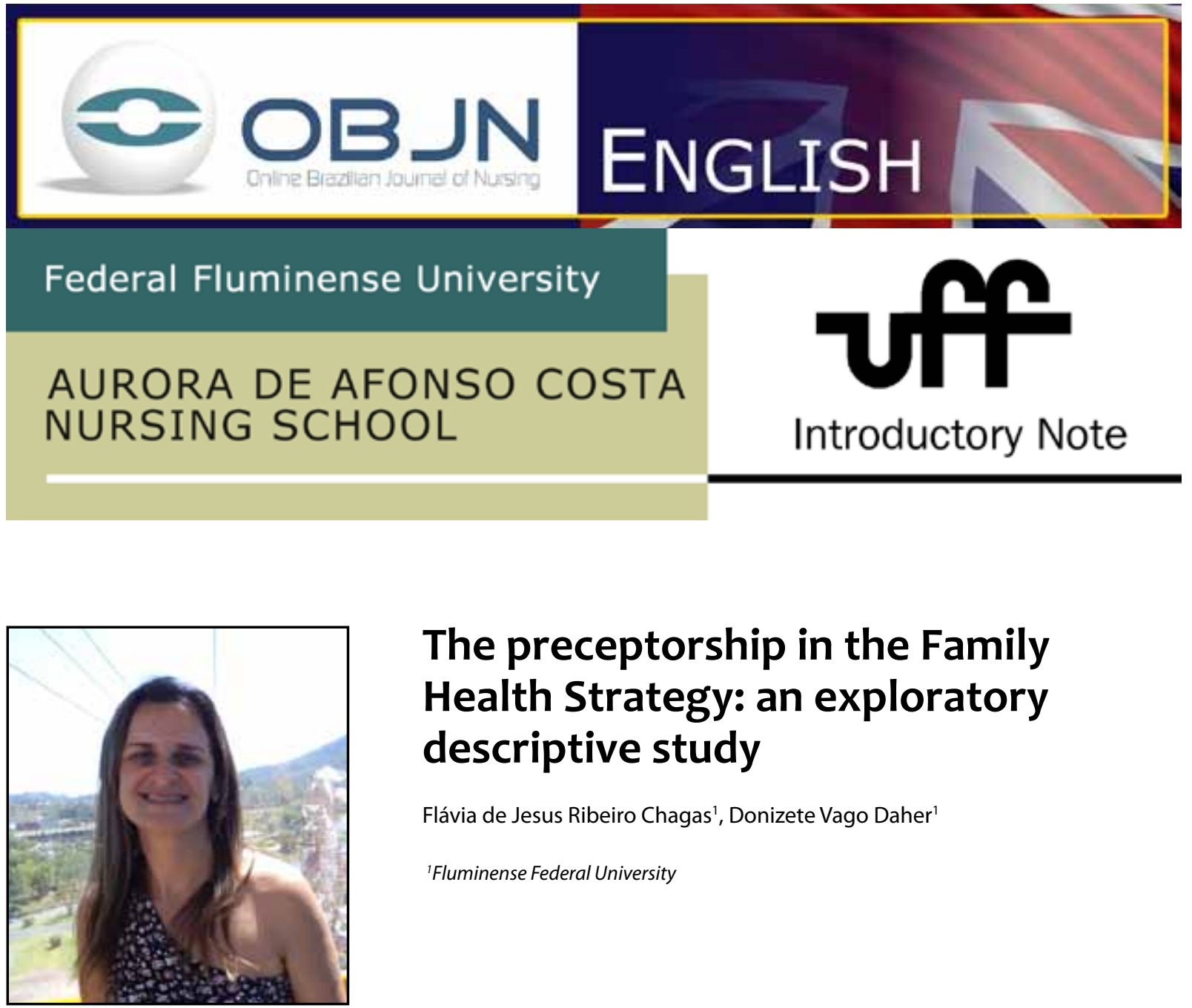

\title{
The preceptorship in the Family Health Strategy: an exploratory descriptive study
}

Flávia de Jesus Ribeiro Chagas', Donizete Vago Daher ${ }^{1}$

${ }^{\prime}$ Fluminense Federal University

\section{ABSTRACT}

Originating from the dissertation project linked to the Professional Master's program in Health Education, Fluminense Federal University, this study aims to reflect on the practice of preceptorship performed by nurses in the Family Health Strategy (FHS) of Itaboraí, RJ.

Aims: To understand the perceptions of preceptors on the FHS in terms of a training scenario; identify the strengths and limitations of preceptors as part of the process of nurse training in the FHS; analyze the appropriate strategies adopted by the preceptors to change the course of training practices; propose training workshops and awareness raising for preceptor nurses with the aim of qualifying training in and for the services involved.

Method: This is a descriptive, exploratory study in which a qualitative approach was used, performed through interviews and participant observation with nurses who act or have acted as preceptors for nursing students.

Descriptors: Preceptorship, Nursing, Family Health Program, Primary Health Care. 


\section{PROBLEMATIC SITUATION AND ITS SIGNIFICANCE}

The Family Health Strategy (FHS) was proposed in 1994 by the Ministry of Health in order to reorient the care model. It is implemented by multidisciplinary teams in delimited territories, prioritizing care to individuals. Its main focus is health promotion and prevention. The relevance of this scenario in the training of future healthcare professionals is evidenced by allowing the insertion of the undergraduate student in the social-political context, as in the communities, we may realize the historicity of every aspect of human life, from the simple act of eating to the daily practices of healthcare ${ }^{(1)}$. Thus, the preceptorship, which aims at teaching in the real situation of the work environment, is inseparable from service practices. The teacher becomes, in this context, the main link between education and service care, between theory and practice. Studies involved with the development and construction of critical awareness and technical and scientific training, in conjunction with the reality of the Brazilian health system, should be part of the daily training in healthcare. Therefore, the concerns related to introducing a discussion of the social and political role of the professional into the training agenda, must be constant, as there is a need to create strong connections that promote permeability between knowledge and the transmission of information ${ }^{(2)}$. As active participants in the teaching-learning process, the preceptors seek to reflect upon the dimensions of their practice and strengthen their pedagogical training. Therefore, understanding the importance of the preceptor in the FHS in terms of the training that focuses on the UHS guidelines, the following topic was chosen: The practice of preceptorship with regard to nurse training as part of the FHS in the city of Itaboraí.

\section{GUIDING QUESTIONS}

What is the perception of the preceptor within the FHS as the setting for nurse education? Which potentialities and limitations are encountered by preceptors in their nurse training practices in FHS scenarios?

Which strategies are appropriate for these professionals when it comes to developing their activities as preceptors?

\section{AIMS}

General

Understand the perceptions of preceptors on the FHS in terms of a training scenario.

\section{Specifics}

Identify the strengths and limitations of preceptors in the training process with regard to nurses in the ESF;

Analyze the appropriate strategies for preceptors in order to reorient training practices;

Propose a training and sensitization workshop for preceptor nurses with the purpose of qualifying them with regard to training, in and for healthcare services.

\section{METHOD}

A descriptive exploratory study in which we used a qualitative approach, that works with the universe of meanings, motives, aspirations, beliefs, values and attitudes. This set of human phenomena is understood as part of a social reality, because the human being is distinguished, not only for acting, but also for thinking about what he does and for interpreting such ac- 
tions within and from the reality experienced and shared with their peers ${ }^{(3)}$. The study will be developed in Itaboraí, RJ which belongs to Metropolitan Region II. It will have coverage of $70 \%$ of the region through 44 FHS teams. The study subjects are the preceptor nurses of the FHS of this municipality. The inclusion criterion was being a nurse who works or has worked in the past 12 years as a teacher in the FHS of this city and, as an exclusion criterion, nurses who work in management activities. All participants will be questioned about their willingness to participate in the study, and will be required to sign the consent form. The study will be conducted in the second half of 2013 through a field study, with the use of semi-structured interviews and participant observation, using a script that was developed and subjected to a pilot test by the researchers. After collecting the data we will start the analysis of the interviews and observations with the exploration and description of the data by means of thematic content analysis. The study was submitted to the Research Ethics Committee on $08 / 27 / 2013$ and awaits approval.

\section{REFERENCES}

1. Barreto VHL, Monteiro ROS, Magalhães GSG, Almeida RCC, Souza LN. Papel do preceptor da atenção primária em saúde na formação da graduação e pós-graduação da Universidade Federal de Pernambuco - um Termo de Referência. Rev bras educ méd. 2011; 35 (4): 578-83.

2. Cezario JEP, Daher DV. Partnership between education and the workplace for the development of new nurses: an exploratory study. Online braz j nurs [Internet]. 2012 Oct [cited 2013 Sept 5]; 11 (2):492-5. Available from: http://www.objnursing. uff.br/index.php/nursing/article/view/3955. doi: http://dx.doi.org/10.5935/1676-4285.2012S018

3. Minayo MCS, organizadora. Pesquisa Social: teoria, metodologia e criatividade. 31. ed. Petrópolis: Vozes; 2012.

\section{Project Data}

Project Dissertation submitted to the Professional Master's Program in Health Education at the Universidade Federal Fluminense.

Received: 01/09/2013

Revised: 04/09/2013

Approved: 06/09/2013 